\title{
A systematic review approach of mobile technology adoption in higher education
}

\author{
Anantha Raj A. Arokiasamy
}

Xiamen University Malaysia,

Persiaran Sunsuria, Bandar Sunsuria, 43900 Sepang, Selangor, Malaysia

Dr, School of Economics and Management

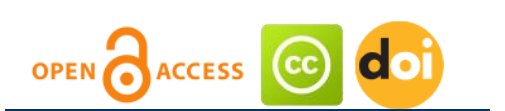

Article history:

Received: June 29, 2017

1st Revision: September 10, 2017

Accepted: October 27, 2017

\section{JEL classification:}

A22

D83

I23

DOI:

10.14254/jems.2017.2-2.5

\begin{abstract}
Many educators agree that mobile technology has great potential not only to improve our educational practices but also to change traditional learning platforms and classroom learning environments. There are also many advantages to integrating mobile technology into the $21^{\text {st }}$ century classrooms to support teaching and learning. Mobile technology tools such as iPads, iPad mini, mobile applications, tablets, palm devices, e-readers and smartphones are becoming real-world tools that should be integrated into modern instructional practices to support digital learners and to promote meaningful learning. Educators are harnessing mobile devices within and beyond the classroom due to the flexibility, portability, affordability and popularity of those devices. This study explores the effectiveness of mobile technology adoption within $21^{\text {st }}$ century classrooms processes and outcomes.
\end{abstract}

Keywords: mobile technology adoption, higher educational, technology tools, educational purposes, mobile devices.

\section{Introduction}

This study focuses on three key areas of innovation in teaching and learning in higher education today: smartphone devices, texting applications and multipurpose, multimedia mobile communicative applications such as Skype. Today's educators have at their disposal a wide array of digital technologies that enable them to enhance the teaching and learning process. These technologies, coupled with more valid and reliable learning theories are revolutionizing the way we teach and are altering our notions of what it means to learn and live in a post-industrial, globalized world. Both individually and socially, these new mobile technologies are becoming increasingly popular and useful as educational tools across a wide range of disciplines as a means to engage and retain students (Arokiasamy et al., 2014). If used appropriately and purposefully, these mobile technologies are well suited for the increasingly interconnected and interdependent world we live

E-mail: anantharaj.arokiasamy@xmu.edu.my 
in and they provide educators with another set of tools by which to enrich the teaching and learning process and educational outcomes (Ariffin, 2011).

Lim et al. (2011) denotes that as the cost associated with these technologies comes down, they become more widely used in society and this prevalence helps to facilitate social change by creating new ways to interact with each other. These technologies include new hardware devices such as smartphones and new software applications such as Skype. In addition, this mass diffusion of mobile technologies is being driven by a convergence of technologies that increasingly allows these technologies to interconnect and communicate with each other in a more seamless way. As such, the traditional boundaries between phones and computers and the Internet are becoming more and more integrated. For instance, traditional mobile phones now act more like computers and traditional computers now act more like phones. Voice data and video continue to converge across these platforms with the Internet as the common medium of exchange (Murphy \& Farley, 2012). However, these mobile technologies do not just allow us to do our jobs more efficiently and more effectively, they also provide educators with many new possibilities and opportunities to enhance and transform how we connect and interact with our students and our colleagues.

As such, they provide us with a means to greatly expand our notions of learning and our notions of the purpose of education, providing us with a potentially broader definition and scope of teaching, learning and education. The challenge then becomes how do we embrace these new opportunities while at the same time, continue to maintain the ethos of the academy (eg; academic freedom, pedagogical pluralism) and continue to maintain a high level of academic quality (eg; academic integrity and rigor, professional development) (Buckenmayer, 2008). However, it should be noted, as with all technologies that the uniqueness alone of these technologies is not sufficient to engage and retain learners. As with any teaching and learning technology or approach, these technologies must be used in a purposeful and meaningful way and they must be integrated within a relevant theoretical framework that is appropriate to the teaching and learning context. Using valid and reliable pedagogical methods and learning principles and theories is vital since they form the basis for predicting human behavior and expected learning outcomes (Cavus et al., 2008). Again, as with all technologies, in addition to relevant and established theory, it is also imperative to be cognizant of the epistemological, ontological and phenomenological basis that are germane to utilizing such technologies (Cruz et al., 2012).

\section{Literature review}

\subsection{Adoption principles}

There are two key principles that emerged from this finding for mobile technologies:

A) Mobile learning environments should be viewed as global communities in which access to learning is not restricted by externally imposed space and time constraints but rather where flexible learning is valued and practiced by both instructors and students and where learning (both formal and informal) and academic engagement occurs all space and time boundaries (eg; political, economic, social, physical).

B) Anytime, anywhere learning environment have the potential to foster a greater sense of immediacy, interactivity and authenticity, due to their built-in flexibility and learner selfefficacy and learning autonomy can be increased by fostering self-regulated learning by promoting situational learning (eg; time and space conditions that are more suitable to the needs of the learner) by cultivating a diversity of learning contexts and by nurturing more dynamic and spontaneous learning opportunities.

These principles are indicative of the growing need to seamlessly interact with others in a post-industrial, globalized network world that is characterized by interdependence and interconnectivity. Educational institutions and faculty should take the lead in preparing students for life in this rapidly evolving world. Thus, these technologies provide the potential to open up access to learning for a larger number of students who may not be able to overcome the constraints and boundaries imposed by traditional classroom settings, including fixed e-learning environments (Kafyulilo, 2012). The use of Skype and other mobile technologies can provide a useful way to enhance learning. Thus, if designed properly and integrated into the course in a purposeful manner, mobile technologies can provide today's learners with a more sustainable and practical means to augment their learning experience, especially since today's learners are increasingly accustomed to sing mobile technologies as a normal part of their lives. As such, higher education institutions should continue to adopt to this digital world in ways that better suit contemporary lives of learners (Lee et al., 2011). 


\subsection{Application benefits}

As illustrated in this study on the application section, these types of leaner-centered mlearning environment support:

a) Contextual and situational learning where learning naturally occurs across home, work and school domains in a multiplicity of complex situations and contexts and where context is constructed by the complex interplay of situated interactions.

b) Open-ended and flexible learning in both formal and informal ways, where learning is flexible and more naturally distributed to suit the context and the needs of the learner.

c) Distributed and ubiquitous learning where the responsibility for learning and the locus of control of learning is distributed across learners, instructors, mediating technologies and knowledge resources.

d) Sustainable and self-regulated learning that fits better and more naturally with learning that occurs across the varied life stages of learners, where learning is a natural life-long activity and

e) Personalized and authentic learning that is personally meaningful to each learner and more conducive to how today's learners engage with their life-world environment.

In other words, learning tends to be more effective when learning is more meaningful and relevant to the ways students live their lives. In short, the question becomes: How do we construct more effective learning spaces such that given that a large part of learning takes place outside the formal classroom setting? (Kafyulilo, 2012). Most learners today are continuously mobile, highly networked and make use of mediated communication technologies. This contemporary lifestyle often transcends traditional space and time boundaries and as such, the mediating technologies we use as a normal part of our contemporary lives are transforming the ways in which we work, live and learn (Lee et al., 2011). Thus, the role of teaching and learning is also shifting from a passive un-directional instructional paradigm where the locus of control resides exclusively with the instructor to a more active multidirectional networked teaching and learning paradigm where the locus of control is more distributed. In this emerging paradigm, we must re-conceptualize the meaning of learning within the context of the post-industrial age. Mobile technologies are playing an increasing role in the evolution of this emerging paradigm (Serin, 2012).

\subsection{Technology}

One of the tools we focus on this research-Skype is a good example of a technology that facilitates the building of and provides a platform where students can engage in m-learning. Skype is a hybrid peer-to-peer and client server technology that allows people to connect and communicate using voice, video conferencing and data. Skype is one of the most ubiquitous mlearning tools with over 700 million users worldwide (Zulkafly et al., 2011). M-learning focuses on the needs of mobile learners and instructors anytime, anywhere accessibility of academic resources, content and communication with follow learners and instructors is the underlying benefit of m-learning. M-learning technologies should be congruent with the learning objectives of the course. Since cost is normally not the issue since many mobile applications such as Skype are, at the present time free to use, then the main challenge is ensuring that students have access to the hardware devices (Wang et al., 2009). Nonetheless, these technologies have generally improved to the point where learning within this context should be beneficial for the learner and provide a more flexible and authentic means to increase academic achievement.

\subsection{Future role of mobile technology in education}

As the world increasingly becomes networked with nearly universal high-speed Internet connectivity, Smartphones technologies are also becoming more ubiquitous with enhanced capabilities for rich text, voice/audio and video media ideal for learning at any pace, anytime and anywhere. Learning will move more and more outside of the classroom and into the learner's environment, both real and virtual, thus becoming more saturated, personal, collaborative and lifelong (Zulkafly et al., 2011). There can be no doubt that mobile technology will play a major role in the future of education, especially given the fact that such technologies are more in tune with this first-paced information age. The world has seen numerous monumental inventions and changes that have had lasting impact on human life but the invention of the Internet and its integration within mobile technologies seems to be the single most powerful invention, redefining every perceivable sector of life including education. This invention and catalyst of change is certainly 
poised to redefine the educational approach and even the underlying concept of literacy (Zulkafly et al., 2011).

Nothing else has revolutionized mobile technologies more than Smartphone, a device that has now become synonymous with our daily way of life. Mobile technology is successfully and systemically helping to remove both time and space constraints associated with the traditional classroom-based education (Ahmadi et al., 2011). Despite the challenges the Smartphone technology is still facing to effectively enable adequate dissemination of education in Malaysia, it is certain that mobile technologies are poised to be the future means for increasing education access in the region.

\subsection{Teaching with mobile technology}

Mobile technology as Apple iPad and iPhone, have tremendous educational potential with over 108,000 educational application (apps) available for use in the classroom (Sherry \& Gibson, 2002). Pollara and Broussard (2011) denotes that Apple reports selling over 8 million iPads around the world directly to education with more than 4.5 million sold to US based educational institutions. The iPad is currently the dominant mobile tool and the technology of choice for schools, likely due to the stability of the operating system and availability of educational apps. Schools across the US and around the world are actively exploring educational use of this mobile technology (Bloom et al., 2011).

Technology is driving the change in the way students are learning, cognitively and concretely and is altering their perspective and the reality of how their learning occurs (Wang \& Wu, 2013). Results from a recent study by Cochrane (2010) reveal that when college students were given an iPad in their college classroom, their stated benefit was to use them as an e-reader and as a device for instant accessibility of information during the instructor's lecture. Subsequently as technology has changed the way students learn and view learning, it must also change the way teachers teach and view teaching. Standards are also a part of the push for change as they are an integral part of the educational landscape and when it comes to technology the situation is no different. There are now in place to delineate the technology skill that all teachers should have in order to teach in the $21^{\text {st }}$ century classroom.

Today's teachers are instructing students who are immersed in the current technologies, who can and have the expectation to be able to access information on demand and who remain continuously connected to their world (Cheon et al., 2012). These learners have been labelled as digital natives and today's teachers referred to as digital immigrants (Ahmadi et al., 2011). The inherent digital nativeness of current and future college/university students requires school to reimagine the role and method of instruction to promote student learning and thinking. In particular, university professors can no longer continue using what West demand the "medieval clerk" approach to reading, writing, counting and memorizing lectures and texts but must move toward integration of information and communication technologies. Typically, current thinking postulates teachers are as a general rule, less adept and comfortable with the plethora of available, ubiquitous technology tools than are the students they are teaching (Ghavifekr et al., 2012). Educators can also be slow to embrace change and often prefer the traditional teaching models in which an instructor delivers content to a roomful of students (Hatlevik \& Arnseth, 2012). Teachers may question how mobile technology is any different from innovations such as laptop computers or interactive white boards. What are the benefits? What are the drawbacks? Teachers may hesitate to add the latest "gadget" to their arsenal of technology and (Kozma \& Anderson, 2002) point out, teachers feel tremendous pressure to cover standards and prepare their students for high stakes tests rather than focus on $21^{\text {st }}$ century goals.

The most recent research in mobile technology learning indicates that many educators are in the early stages of mobile technology adoption and are looking for ways to use technology as a way to transform their teaching (Seet \& Quek, 2010). This transformation requires educators to think outside the box in order to capture the full capabilities of this ubiquitous technology. Ubiquitous access to information is now the norm. In turn, this requires effective professional development to prepare educators to use mobile technology to redefine their teaching to meet the needs of today's learners.

\subsection{Benefits of mobile technology in education}

It is easy to provide a list of benefits of mobile devices, especially when it comes to their impact outside of education. Social media, text messaging and entertainment apps make it easier for a person to shop online, deposit a check through a Smartphone and connect with a person half- 
way across the world. Although Smartphones may not be the first thing that comes to mind when thinking of the revolutionary benefits of mobile devices, one cannot dismiss that Smartphones and other mobile devices can also open the doors to education (Yuen et al., 2008). Smartphone users are able to virtually "check in" to places, announcing to friends in their network that they have arrived at a particular building, restaurant or class through the "share" function integrated into location-based application. Students are able to share instantly their location on Facebook and Twitter via location identification technologies or location-aware technologies, which disclosure where people in a user's network actually are (Alzaza \& Yaakub, 2011). The convenience that Smartphones afford their users has made them a necessity for many people, including college students on campus across the United States and abroad.

Studies have suggested that the motivating factor for Smartphone usage by students is social networking, whereas family and security were the motivating factor for adults. Mobile technology allows users to stay connected and also fill in time when they find themselves idle. For example, one will observe college students casually staring at their Smartphones screens while waiting for a bus or waiting to get into a class. The result from this study suggest that Smartphones increase the functionality of phones (Iqbal \& Qureshi, 2012). Their study also suggests that college students have integrated the Internet into many facets of their lives. Undoubtedly, mobile devices usage among students have reduced enormously the communication gap in many developing countries because, today, more students have unprecedented access to information as a result of the expanding Internet and mobile telecommunication network connectivity. The penetration of the Internet and Smartphone usage has enabled digital communication activities to occur among masses of students anytime, anywhere or at any pace. This could be a benefit that educators can exploit to reach many more learners than what the traditional face-to-face mode of education delivery can reach (Kim-Soon et al., 2014).

There are numerous education-related benefits associated with mobile technology but the major ones include the capability to provide mass education access, faster data transmission speed capability, accessibility of various media platforms, availability of a variety of mobile devices, affordability of mobile devices, linkages between mobile technology and social media, minimal training requirement to operate mobile devices, size and weight advantage of mobile devices, capability for users to customize and personalize features and integration of mobile technology with the Internet. Each of these benefits or advantages associated with mobile technology especially in the context of education are further discussed below:

\subsection{Affordability of Mobile Devices}

As discussed above, there is an unprecedented proliferation of mobile devices, which has resulted in the cost of these devices to decrease overtime. Today, in many developing countries people can at least afford to own some sort of a mobile device, particularly a mobile phone. Consequently, mobile devices hold out enormous promise as the single mobile device most likely to help deliver education to more learners in underdeveloped and developing countries and perhaps on a sustainable, equitable and scalable basis (Jones \& Jo, 2004). Besides the affordability of mobile devices, rates such as mobile termination rates are reducing tremendously across many parts of the world. According to a report from Research ICT America, regulators have enabled competition by entering cost-based mobile termination rates; the resulting competition has driven down prices for consumers (Lee et al., 2013) and hence increased affordability. Besides the reducing termination rates, it is becoming inexpensive to develop apps for mobile technology platforms and as a result, there is an increasing availability of more free and low-cost apps, many of which are suitable for education. Without a doubt, mobile devices especially mobile phones, have the potential to become delivery mechanisms of low-cost learning to people previously deprived the benefits of an education.

\section{Conclusion}

Mobile technology has now made it possible for numerous computing tasks to be easily accomplished on-the-go. As a result, every sector including education is embracing mobile technology to take advantage of the benefits that come with such technologies. The education sector is legitimizing the dissemination of learning via mobile devices and mobile learning is becoming synonymous with education. Traditional education delivery within the confines of "brick and mortar" is struggling to catch up with the rapidly increasing demand for education in developing countries (Hyman et al., 2014). Educators and education stakeholders need to quickly find alternative avenues through which education can be disseminated to more learners without restrictions of space, time and pace. 
Apparently, mobile technologies seem to be the probable solution and an investment in such technologies could guarantee future and lasting payoffs for the education sector. Therefore, university and faculty members should ensure that students effectively use the technology for learning purposes; otherwise the technology becomes redundant. More importantly, technology reduces paper usage and saves the environment to a certain extent (Menkhoff \& Bengtsson, 2012). Educators and government leaders in Malaysia should seriously look into this seemingly unconventional way of disseminating education as a possible and perhaps practical alternative to help tackle the issue of education access (Martin \& Ertzberger, 2013). The implications of mobile technology learning on higher education are far reaching. Consequently, it will not be surprising that people around the world will begin to embrace mobile technology as a significant part of their educational process. Considering the trend, mobile technology could be a boom in Malaysian higher education within the next few years and this has called for all policy makers and stakeholders to be ready for it. A thorough understanding of how students are already using their mobile devices to support learning could lead to the more effective and sustainable deployment of mobile technology learning initiatives across the sector (Yu et al., 2013).

\section{Appendix A. Supplementary material}

Supplementary data associated with this article can be found, in the online version, at https://dx.doi.org/10.14254/jems.2017.2-2.5

\section{Funding}

The authors received no direct funding for this research.

\section{Citation information}

Arokiasamy, A. R. (2017). A systematic review approach of mobile technology adoption in higher education. Economics, Management and Sustainability, 2(2), 48-55. doi:10.14254/jems.2017.2-2.5.

\section{References}

Ahmadi, S., Keshavarzi, A., \& Foroutan, M. (2011). The Application of Information and Communication Technologies (ICT) and its Relationship with Improvement in Teaching and Learning. Procedia-Social and Behavioral Sciences, 28, 475-480.

Alzaza, N. S., \& Yaakub, A. R. (2011). Students' Awareness and Requirements of Mobile Learning Services in the Higher Education Environment. American Journal of Economics and Business Administration, 3(1), 95-100. doi:10.38441ajebasp.2011.95.100.

Ariffin, S.A. (2011). Mobile Learning in the Institution of Higher Learning for Malaysia students: Culture perspective. In Proceeding of the International Conference on Advanced Science, Engineering and Information Technology 2011.

Arokiasamy A., Abdullah, A.G.K., \& Ismail, A. (2014). Correlation between Cultural Perceptions, Leadership Style and ICT Usage by School Principals in Malaysia. TOJET- Turkish Online Journal of Educational Technology, 13(3), 27-40.

Bloom, B., Englehart, M. Furst, E., Hill, W., \& Krathwohl, D. (1956). Taxonomy of educational objectives: The classification of educational goals. Handbook I: Cognitive domain. New York, Toronto: Longmans, Green.

Buckenmayer, J. (2008). Revisiting teacher adoption of technology: Research implications and recommendations for successful full technology integration. College Teaching Methods \& Styles Journal, 4(6), 7-10.

Cavus, N. \& Ibrahim, D. (2009). M-learning: An experience in using SMS to support learning new English language words. British Journal of Educational Technology, 40(1), 78-91.

Cavus, N., Bicen, H., \& Akeil, U. (2008, June). The opinions of information technology students on using mobile learning. Paper presented at the 08 International Conferences on Educational Sciences, Magosa, North Cyprus.

Cheon, J., Lee, S., Crooks, S. M., \& Song, J. (2012). An investigation of mobile learning readiness in higher education based on the theory of planned behavior. Computers \& Education, 59(3), 1054-1064. doi:10.1016/j.compedu.2012.04.015. 
Cochrane, T. D. (2010). Exploring mobile learning success factors. Association for Learning Technology Journal, 18(2), 133-148. doi:10.1080/09687769.2010.494718.

Cruz Y., Assar, S., \& Boughzala, I. (2012). Exploring teacher's perception and potential use of Mobile Learning in a Business School. Paper Presented at the 18th Americas Conference on Information Systems, Washington, United States of America.

Echeverría, A., Nussbaum, M., Calderón, J. F., Bravo, C., Infante, C., \& Vásquez, A. (2011). Face-to-face collaborative learning supported by mobile phones. Interactive Learning Environments, 19(4), 351-363.

Garrison, D. R. (2011). E-learning in the 21st century: A framework for research and practice (2nd Ed.). London: Routledge/Taylor and Francis.

Ghavifekr, S., Afshari, M., \& Amla Salleh. (2012). Management strategies for E-Learning system as the core component of systemic change: A qualitative analysis. Life Science Journal, 9(3), 2190-2196.

Hatlevik, O. E., \& Arnseth, H. C. (2012). ICT, teaching and leadership: How do teachers experience the importance of ICT-supportive school leaders. Nordic Journal of Digital Literacy, 7(1), 5569.

Hyman, J. A., Moser, M. T., \& Segala, L. N. (2014). Electronic reading and digital library technologies: Understanding learner expectation and usage intent for mobile learning. Educational Technology Research and Development, 62, 35-52.

Iqbal, S. \& Qureshi, L. A. (2012). M-learning adoption: A perspective from a developing country. The International Review of Research in Open and Distance Learning, 3(3), 147-164.

Jones, V., \& Jo, J. H. (2004, December). Ubiquitous learning environment: An adaptive teaching system using ubiquitous technology. In Beyond the comfort zone: Proceedings of the 21st ASCILITE Conference (pp. 468- 474).

Kafyulilo, A. (2012). Access, use and perceptions of teachers and students towards mobile phones as a tool for teaching and learning in Tanzania. Education and Information Technologies. doi:10.1007/s10639- 012-9207-y.

Kim-Soon, N., Rahman, A. \& Ahmed, M. (2014). E-Service Quality in Higher Education and Frequency of Use of the Service. International Education Studies, 7(3), 1-10.

Koehler, M.J., \& Mishra, P. (2008). Introducing TPCK. In AACTE Committee on Innovation and Technology (Ed.). The handbook of technological pedagogical content knowledge (TPCK) for educators (pp. 3-29). New York, NY: Routledge.

Kozma, R., \& Anderson R. E. (2002). Qualitative case studies of innovative pedagogical practices using ICT. Journal of Computer Assisted Learning, 18, 387-394.

Lee, H., Lee, W. B., \& Kweon, S. C. (2013). Conjoint analysis for mobile devices for ubiquitous learning in higher education: The Korean case. TOJET, 12(1).

Lee, Y. H., Hsieh, Y.C., \& Hsu, C.N. (2011). Adding Innovation Diffusion Theory to the Technology Acceptance Model: Supporting Employees' Intentions to use E-Learning Systems. Educational Technology \& Society, 14(4), 124-137.

Lim, T., Abas, Z. W., \& Fadzil, M. (2011). Helping Distance Learners Stay Connected: The Effectiveness of Mobile Learning via SMS at Open University Malaysia. In 24th AAOU Annual Conference, Hanoi Open University, Vietnam.

Malaysia Education Blueprint 2013-2025. (2013). Preliminary Report. Preschool to Post-Secondary Education. Ministry of Education Malaysia.

Martin, F., \& Ertzberger, J. (2013). Here and now mobile learning: An Experimental study on the use of mobile technology. Computers \& Education, 68, 76-85.

Menkhoff, T., \& Bengtsson, M. L. (2012). Engaging students in higher education through mobile learning: Lessons learnt in a Chinese entrepreneurship course. Educational Research for Policy and Practice, 11(3), 225-242.

Murphy, A. \& Farley, H. (2012). Development of a framework for evaluating the impact and sustainability of mobile learning initiatives in higher education. In M. Brown et al. (Eds.), Future Challenges, Sustainable Futures. Proceedings Ascilite Wellington 2012. (pp. 678-680). 
Pollara, P., \& Kee Broussard, K. (2011). Student Perceptions of Mobile Learning: A Review of Current Research. In Proceedings of Society for Information Technology \& Teacher Education International Conference 2011 (pp. 1643-1650). Chesapeake, VA: AACE.

Puentedura, R. R. (2013, May 29). SAMR: Moving from enhancement to transformation [Web log post]. Retrieved from http://www.hippasus.com/rrpweblog/archives/000095.html.

Rogers, Y., Connelly, K., Hazlewood, W. \& Tedesco, L. (2010). Enhancing learning: A study of how mobile devices can facilitate sense making. Personal \& Ubiquitous Computing, 14(2), 111-124.

Rosman, P. (2008). M-Learning-As a paradigm of new forms in education. E+M Economies and Management, 1, 119-125.

Seet, L. Y. B. \& Quek, C. L. (2010). Evaluating students' perceptions and attitudes toward computer mediated project-based learning environment: A case study. Learning Environments Research, 13(2), 173- 185.

Serin, 0. (2012). Mobile learning perceptions of the prospective teachers (Turkish republic of Northern Cyprus sampling). The Turkish Online Journal of Educational Technology, 11(3), 222-233.

Sherry, L., \& Gibson, D. (2002). The path to teacher leadership in educational technology. Contemporary issues in technology and teacher education, 2(2), 178-203.

Wang, J., Yu, W., \& Wu, E. (2013). Empowering mobile assisted social e-learning: Students' expectations and perceptions. World Journal of Education, 3(2). doi:10.5430/wje.v3n2p59.

Wang, M., Shen, R., Novak, D., \& Pan, X. (2009). The impact of mobile learning on students' learning behaviours and performance: Report from a large blended classroom. British Journal of Educational Technology, 40, 673-695. doi:10.1111/j.1467-8535.2008.00846.x.

Yu, Y. S., Lin, Y. Y., Huang, Y. L., \& Hsieh, W. H. (2013). The Evaluation of use the mobile phone learning English in Taiwan. International Journal of Information and Education Technology, 3(2), 189-191.

Yuen, M. C., Song, H., \& Jong, S. J. (2008). Digital habits of Malaysian students and its implication for learning: a preliminary study. In Proceedings of 2nd International Malaysian Educational Technology Convention - IMETC2008.

Zulkafly, N. A., Koo, A. C., Shariman, T. P. N., \& Zainuddin, M. N. (2011). Educators' perceptions towards Mobile Learning. Paper Presented at the Artificial Intelligence Workshop, Kuala Lumpur, Malaysia.

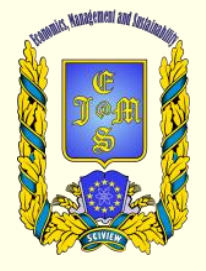

๑) 2016-2017, Economics, Management and Sustainability. All rights reserved.

This open access article is distributed under a Creative Commons Attribution (CC-BY) 4.0 license.

You are free to:

Share - copy and redistribute the material in any medium or format Adapt - remix, transform, and build upon the material for any

purpose, even commercially.

The licensor cannot revoke these freedoms as long as you follow the license terms.

Under the following terms:

Attribution - You must give appropriate credit, provide a link to the license, and indicate if changes were made.

You may do so in any reasonable manner, but not in any way that suggests the licensor endorses you or your use.

No additional restrictions

You may not apply legal terms or technological measures that legally restrict others from doing anything the license permits.

Economics, Management and Sustainability (ISSN: 2520-6303) is published by Scientific Publishing House "CSR",

Poland, EU and Scientific Publishing House "SciView", Poland

Publishing with JEMS ensures:

- Immediate, universal access to your article on publication

- High visibility and discoverability via the JEMS website

- Rapid publication

- Guaranteed legacy preservation of your article

- Discounts and waivers for authors in developing regions

Submit your manuscript to a JEMS at http://jems.sciview.net or submit.jems@sciview.net

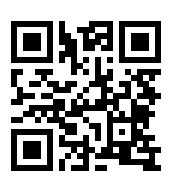

